\title{
Stakeholders' Perception of Coconut Palm Insurance Scheme: A Study on the Coastal States of India
}

\author{
D. Rajasenan ${ }^{1}$ and Rajeev B. ${ }^{2}$
}

\begin{abstract}
The Coconut Palm Insurance Scheme (CPIS) is a mechanism, devised to endow effective risk management aid, to those coconut growers who are likely to be impacted by non-preventable natural factors as well as pests and diseases. This study analyses the perception of the stakeholders for drawing empirical validity, so as to appraise sustainability of CPIS as a measure towards financial inclusion. 528 samples, encompassing Kerala, Karnataka, Tamil Nadu, Goa and Maharashtra states, classified into three regions, were taken using multi-stage proportionate random sampling technique with a view to develop a recurrent scheme to assist the coconut growers. Analyses and inferences, based on Factor Analysis, point out that growers across the regions are convinced that the scheme is necessary for a crop like coconut and, accordingly, the scheme seems to have achieved its goal.
\end{abstract}

Keywords: coconut palm insurance, stakeholders, perception, socio-economics, livelihood security, financial inclusion

${ }^{1}$ Director, International Centre for Economic Policy and Analysis (ICEPA) and Professor in Econometrics, Department of Applied Economics, Cochin University of Science and Technology (CUSAT), Kochi, Kerala, India. Email: rajasenan@cusat.ac.in

${ }^{2}$ Research Assistant, Centre for the Study of Social Exclusion and Inclusive Policy (CSSEIP), Cochin University of Science and Technology (CUSAT), Kochi, Kerala, India. Email: rajeevbhaskars@ gmail.com 


\section{Introduction}

India's share in world coconut production is 15 percent in terms of area and 21 percent in terms of production. Out of the total coconut production in India, the share of coastal states of Kerala, Karnataka, Tamil Nadu, Andhra Pradesh Goa and Maharashtra hovers around 95 percent in terms of quantity and area. Kerala contributes about half of India's total coconut production. Three variants of coconut palms, viz dwarf, tall and hybrid (crossing tall and dwarf varieties) are cultivated in India with some differences in yield and quality. Like other agricultural operations, coconut cultivation is also influenced by weather extremes, natural disasters, pests and diseases. At times, the entire coconut resource of a region gets wiped out due to natural calamity or the onset of pest attack, affecting their livelihood and potentially excluding them from mainstream society.

This article tries to analyze on an interregional basis the perception of stakeholders regarding the CPIS and portrays the drawbacks of the scheme as well as suggestions so as to effectively ensure inclusiveness and overall welfare of coconut growers in India using empirical methods. By analyzing their perception, an attempt is made to understand its effectiveness, and the overall structure and functioning of the scheme at stakeholders' level. This kind of analysis is essential in designing and developing need-based strategies and plans for enhancing their livelihood security.

\section{Coconut Palm Insurance Scheme}

The Coconut Palm Insurance Scheme (CPIS) is a mechanism to endow effective risk management aid to those coconut growers who are likely to be impacted by non-preventable natural factors (storm, lightning, fire, earthquake, landslide, tsunami, etc.), pests, diseases, etc. The scheme was implemented on pilot basis by the Coconut Development Board (CDB) in selected states, viz, Andhra Pradesh, Goa, Karnataka, Kerala, Maharashtra, Orissa and Tamil Nadu. The growers having at least 10 healthy fruitbearing palms to all varieties of coconut, including tall, dwarf and hybrids in specified age groups (4-60 years for dwarf and hybrid, and 7-
60 years for tall) in contiguous area/plot are eligible to join the scheme. Unhealthy and senile palms will be excluded from coverage. The insurance company pays for the loss of palms or for the perils leading to death of the insured palm and when they become unproductive. Premium varies according to age of the palm. For palms between 4 and 15 years, the premium is Rs.4.69 per palm and for 16 to 60 years old palms premium is Rs.6.35 per palm. Insured sum varies from Rs. 600 per palm (for 4 - 15 year age group) to Rs. 1150 per palm (for 16 - 60 year age group). One of the major characteristics of CPIS is the premium subsidy. 50 percent of the premium will be paid by CDB, 25 percent by the State Government concerned and the balance 25 percent will be paid by the farmer/grower. In case the State Government is not willing to bear 25 percent share of the premium, farmers/ growers would be required to pay 50 percent of the premium. Goa has a different pattern of premium sharing compared to the other states as Goa Bagayatdar Sahakari Kharedi Vikri Saunstha Ltd. (a cooperative society in Goa) and Zuari Industries Ltd., Goa, contributes to the farmer's share of premium i.e. 25 percent, thus reducing the burden of farmers. This is done as an endeavor to promote coconut cultivation in Goa.

\section{Theoretical Relevance and Methodology}

A literature scan gives immense illustration of the inter-linkage between risk aversion via agriculture insurance and the resultant financial inclusion. Some studies focus primarily on insurance as a means of protecting losses due to risk and uncertainty; others typically link to productivity, average yield and financial inclusion of the marginalized (Singh, 1972; Pandey et al., 1981; Ramaswami, 1993; Raju and Chand, 2008). This article hypothesizes these theoretical inferences to test the perception of the stakeholders for drawing empirical validity, so as to appraise the sustainability of CPIS as a measure towards financial inclusion. 528 samples encompassing Kerala, Karnataka, Tamil Nadu, Goa and Maharashtra states were taken using the multistage proportionate random sampling technique. 
The five states were further classified into three regions relating to inter regional differences. It also looked at differences in farmers' perceptions about the new pilot scheme, with a view to developing a recurrent scheme to be of assistance for the coconut growers. Factor analysis is used, both regionally and collectively, to identify the significant factors reinforcing the growers' perceptions about the success and sustainability of the scheme.

\section{Results and discussion}

The analysis is focused on acceptance of CPIS, loss of palms and reasons thereof, claim settlement, and adequacy of compensation. There exists disparity in the land holding pattern and the concomitant palms per grower across regions. Holding pattern in Kerala region, by and large is small in comparison to the other two regions, and hence the coconut cultivators in Kerala region on the whole are small farmers, as presented in Figure 1.

Figure 1. Area of cultivation and Total palms per grower

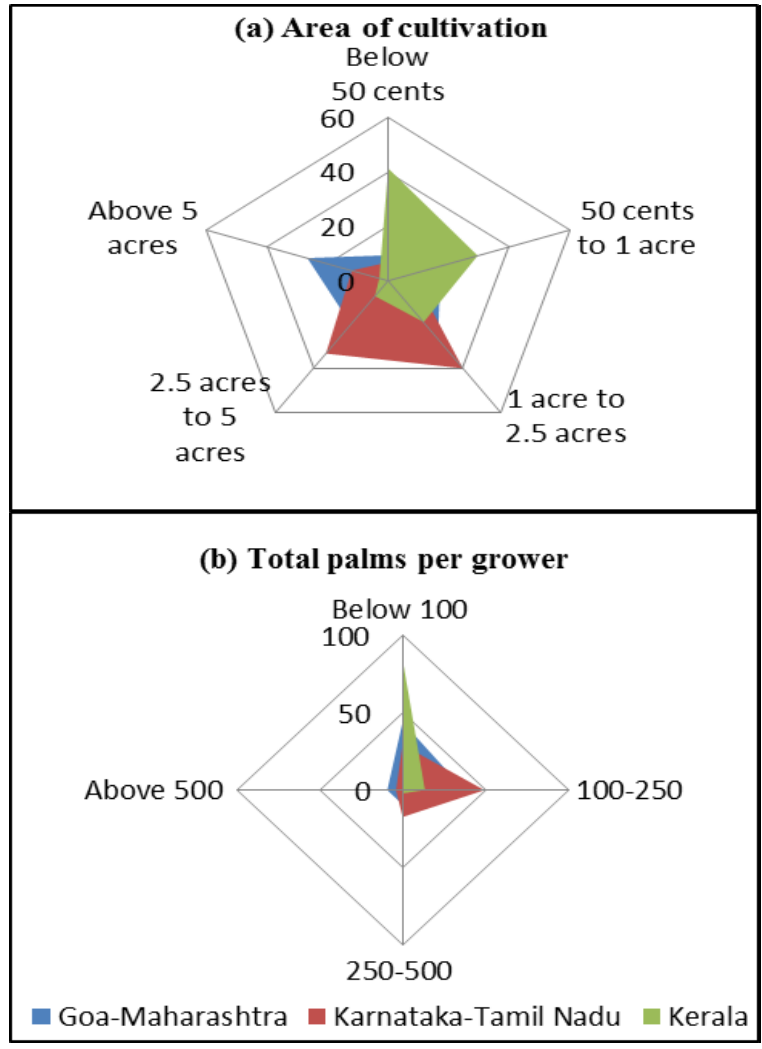

Source: Worked out from survey data (2011-12)

\section{Acceptance of CPIS}

Table 1 (a) shows that most of the respondents approved of the CPIS. However, the ratio is less in Kerala due to the availability of alternate schemes. In Karnataka-Tamil Nadu region, 93.3 percent like the CPIS. Across the regions, the growers find palm insurance against risk of loss as an important protective mechanism. However, senseless stipulations, availability of better alternate scheme (in Kerala), etc. were the major reasons for the dislike (see Table 1 (b)).

\section{Loss of palms after insuring and reason for loss}

Most respondents in Karnataka-Tamil Nadu and Kerala regions (73.3 percent and 82 percent respectively) have lost palms after insuring, whereas in Goa-Maharashtra region, only 49.3 percent have lost palms. Major reasons for loss of palm identified were storm, lightning, heavy rains, various kinds of pests and diseases, etc. In the Goa-Maharashtra region, the major reasons for the loss were pests and diseases together with storm and rain. However, in Kerala region, respondents recorded accidental fire (including forest fire) also as one of the reasons for loss of palms. The multiple response data regarding the loss of palms and major reasons for the loss are shown in Table 2 (a) and Table 2 (b).

\section{Claim settlement and adequacy of Compensation}

Goa-Maharashtra region shows the lowest claim rate of 24 percent. 72 percent of the respondents have made claims in KarnatakaTamil Nadu region and 49.7 percent in Kerala region. It can be inferred from Table 3 (a) that the percentage of respondents claiming is the highest in Karnataka-Tamil Nadu region and the lowest in Goa-Maharashtra region.

Figure 2 (a) portrays the data regarding region-wise number of palms claimed per grower. It can be observed from the data that 28 percent in Karnataka-Tamil Nadu have made no claims, whereas 48 percent have made claims for up to five palms. Respondents claiming between five and ten, and above ten, palms are 12 percent respectively. The percentage of respondents who did not make any claim is the highest in Goa- 
Table 1. Percentage who Like CPIS and who dislike, showing reasons

\begin{tabular}{|l|rrr|rrrr|}
\hline \multirow{2}{*}{\multicolumn{1}{|c|}{ Region }} & \multicolumn{3}{|c|}{ (a) Like CPIS } & \multicolumn{3}{c|}{ (b) Reason for disliking (in percent)* } \\
\cline { 2 - 8 } & Yes & No & Total & $\begin{array}{c}\text { Ineffective } \\
\text { scheme }\end{array}$ & $\begin{array}{c}\text { Other } \\
\text { better } \\
\text { schemes }\end{array}$ & $\begin{array}{c}\text { Senseless } \\
\text { stipulations }\end{array}$ & Other \\
Goa-Maharashtra & 76.0 & 24.0 & 100 & 88.2 & 0 & 70.6 & 76.5 \\
Karnataka-Tamil Nadu & 93.3 & 6.7 & 100 & 80.0 & 0 & 100 & 40.0 \\
Kerala & 66.7 & 33.0 & 100 & 72.6 & 28.3 & 62.4 & 19.0 \\
\hline
\end{tabular}

*Multiple response sets

Source: Worked out from survey data (2011-12)

Table 2. Loss of palm and reasons for loss

\begin{tabular}{|c|c|c|c|c|c|c|c|c|c|}
\hline \multirow{2}{*}{ Region } & \multicolumn{3}{|c|}{ (a) Loss of palm } & \multicolumn{6}{|c|}{ (b) Reason for loss* } \\
\hline & Yes & No & Total & $\begin{array}{c}\text { Heavy } \\
\text { rains }\end{array}$ & Flood & $\begin{array}{c}\text { Pests and } \\
\text { diseases }\end{array}$ & Fire & $\begin{array}{l}\text { Earth } \\
\text { quake }\end{array}$ & $\begin{array}{l}\text { Severe } \\
\text { drought }\end{array}$ \\
\hline Goa-Maharashtra & 49.3 & 50.7 & 100 & 24.3 & 0 & 83.8 & 0 & 0 & 0 \\
\hline Karnataka-Tamil Nadu & 73.3 & 26.7 & 100 & 45.5 & 0 & 85.5 & 0 & 0 & 0 \\
\hline Kerala & 82.0 & 18.0 & 100 & 13.6 & 0.3 & 82.5 & 23.9 & 0.3 & 0 \\
\hline
\end{tabular}

*Multiple response sets

Source: Worked out from survey data (2011-12)

Table 3. Number of claims, adequacy of compensation and scope for improvement of CPIS

\begin{tabular}{|c|c|c|c|c|c|c|c|c|c|}
\hline \multirow[t]{2}{*}{ Region } & \multicolumn{2}{|c|}{$\begin{array}{l}\text { (a) } \\
\text { Claims } \\
\text { made }\end{array}$} & \multicolumn{2}{|c|}{$\begin{array}{l}\text { (b) } \\
\text { Adequacy to } \\
\text { meet the loss }\end{array}$} & \multicolumn{2}{|c|}{$\begin{array}{c}\text { (c) } \\
\text { Replanting } \\
\text { the palm }\end{array}$} & \multicolumn{2}{|c|}{$\begin{array}{c}\text { (d) } \\
\text { Improvement } \\
\text { of CPIS }\end{array}$} & \multirow[t]{2}{*}{$\begin{array}{c}\text { Total } \\
\text { (a) } /(\mathbf{b}) /(\mathbf{c}) /(\mathbf{d})\end{array}$} \\
\hline & Yes & No & Yes & No & Yes & No & Yes & No & \\
\hline Goa-Maharashtra & 24.0 & 76.0 & 11.1 & 88.9 & 0 & 100 & 68.0 & 32.0 & 100 \\
\hline $\begin{array}{l}\text { Karnataka- } \\
\text { Tamil Nadu }\end{array}$ & 72.0 & 28.0 & 55.2 & 44.8 & 51.7 & 48.3 & 83 & 17.0 & 100 \\
\hline Kerala & 49.7 & 50.3 & 44.2 & 55.8 & 66.6 & 33.3 & 77.0 & 23.0 & 100 \\
\hline
\end{tabular}

Source: Worked out from survey data (2011-12) 
Maharashtra region (74.7 percent). Percentage of respondents claiming more than 10 palms is the highest in Karnataka-Tamil Nadu region. In Kerala region, 48.4 percent have not made any claims; whereas 37.8 percent have claimed between 1 to 5 palms.

Figure 2. Number of palms claimed per grower and settlement time

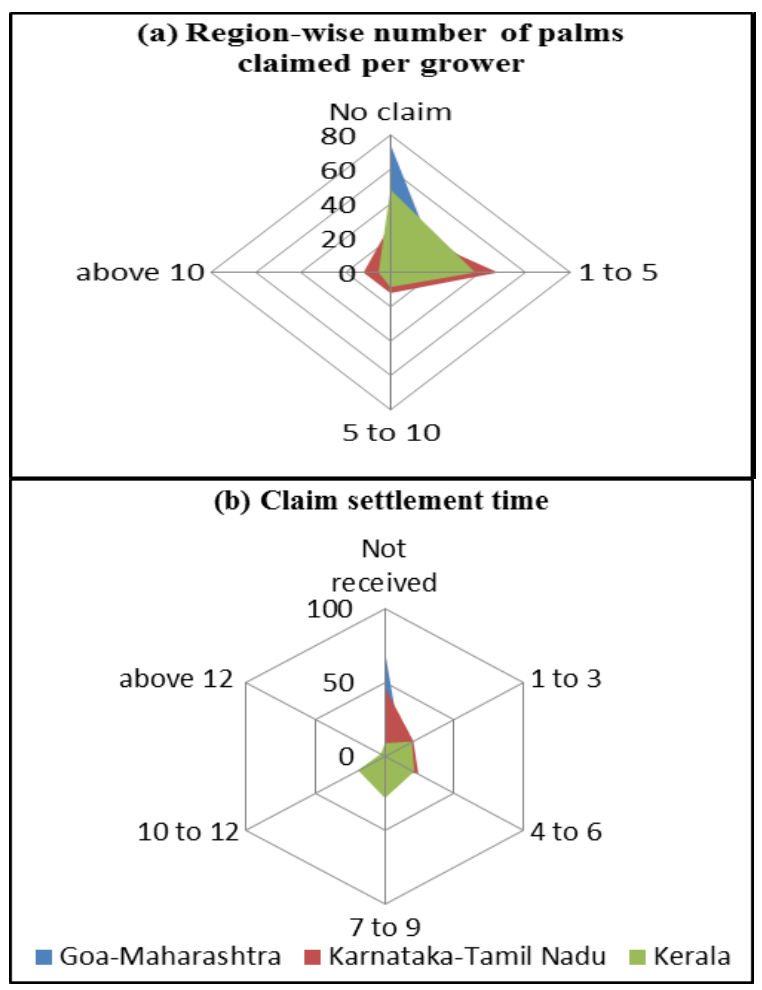

Source: Worked out from survey data (2011-12)

Time taken to settle the claim is one of the important factors determining the success of the scheme. More time for settlement or nonsettlement of claims will adversely affect the implementation of the scheme as growers may show disinterest to continue because their claims were not settled on time or not settled at all. It can be observed that out of the respondents who had made claims, 70.6 percent and 46.3 percent respectively of Goa-Maharashtra and KarnatakaTamil Nadu regions have not received any compensation. In Kerala, more than 20 percent of the respondents had to wait for 10 months or above to get compensation. The majority (72 percent) of the respondents in Kerala region had to wait for more than 4 months to get the claim settled. However, only 8.6 percent have not got their claims settled in Kerala region, which is the lowest compared to the other two regions. The inferences are further reiterated through Figure 2 (b). Even though the period of settlement is longer in Kerala, the probability of settlement is also higher compared to other regions. More waiting time may be due to the procedural delay in settlement, insufficient staffing, heavy workload of officials, engagement of staff for other duties, etc. Longer waiting time/nonsettlement of claims will adversely affect replanting of the palms. The scheme intends to equip the farmers to replant and make up the loss incurred in due course and hence any delay or non-payment of compensation is against the very objective of the scheme. In this context a parallel statement can be evolved, i.e. 'compensation delayed is compensation denied' on the footsteps of the proverbial statement 'justice delayed is justice denied'.

\section{Adequacy of Compensation}

Regarding the adequacy of the insurance in meeting the loss, it is evident from Table 3 (b), that majority in Goa-Maharashtra are of the opinion that the compensation amount is inadequate to meet the loss incurred. Once a new seedling palm is planted, it will begin to yield fruit only after a period of 4-7 years, providing no returns during that period. Compensation paid does not take into account the loss of income to the farmer due to the loss of palm as well as the cost of replanting the same. It was also observed during the field investigation that the yield per palm in Goa-Maharashtra region is much higher compared to other regions, possibly due to better irrigation facilities and fertility of land. Hence, each and every palm is precious and its loss makes a lot of financial and other hardships. The respondents of this region feel that the compensation amount is inadequate to meet the loss. It is pertinent to note that an increase in the compensation amount for high yielding areas will act as a catalyst for higher participation, as well as to sustain the yield. In Kerala, 44.2 percent feel that the compensation amount is adequate enough to meet the loss incurred, may be due to the receipt of compensation from other schemes. 


\section{Replanting}

The idea of the CPIS is to equip the growers to replant the lost palm. But, contrary to this, the majority of the growers in GoaMaharashtra region were of the opinion that the insurance scheme did not render any help or support to them for replanting the palm. This may be due to the fact that 70.6 percent of the respondents of this region have not received any compensation for claims they have made. The compensation is, in effect, covers only loss of production from the lost palm, while the cost of replanting the palm remains a burden to the farmers. In Karnataka-Tamil Nadu region, the growers have not replanted due to the lack of irrigation facilities. The respondents in this region are waiting for the right season i.e. monsoon, for replanting. 51.7 percent in Karnataka-Tamil Nadu and 66.7 percent in Kerala region opined that the compensation is adequate to replant the palm. The detail of this is given in Table 3 (c).

\section{Improvement of CPIS}

It is obvious from Table 3 (d) that the majority of respondents want an improved CPIS scheme some way or the other. 68 percent in Goa-Maharashtra, 83 percent in KarnatakaTamil Nadu and 77 percent in Kerala opined that CPIS should be improved. The majority of the sample respondents want the scheme to be finetuned to become more farmer-friendly. The respondents were also asked to provide their suggestions to make this scheme better, which are discussed in the subsequent sections. In Kerala region, the majority voiced for the merging of CPIS with the state insurance scheme. Most of the respondents across regions cite the necessity for making terms and conditions rational. Long delay for claim settlement was yet another issue identified by the growers which needs to be resolved. The growers also stipulate the necessity for more active participation from the authorities (both insurance company and agriculture/horticulture officials concerned) in conducting periodic field visits, awareness programmes, interim evaluations, etc. of the farms.

\section{Drawbacks of CPIS}

From among the twenty or more drawbacks identified by the growers, 12 most frequently suggested drawbacks were identified based on the perception of growers. To divulge the drawback system evidently the 12 drawbacks factors were subdivided into three reduced categories (issues with scheme particulars, issues with communication and issues with claiming procedures) using Factor Analysis.

Variables identified and their categorization is illustrated in Table 4. Regionwise analysis identifies specific drawbacks of CPIS. Across all regions, the Kaiser-MeyerOlkin (KMO) measure of sample adequacy shows a value of greater than 0.5 and hence recommends the analysis to proceed. Bartlett's Test is also significant and its associated probability is less than 0.05 . Results of KMO and Bartlett's Test are portrayed in Table 5.

Table 4. Drawbacks of CPIS - factors identified

\begin{tabular}{|l|l|}
\hline \multicolumn{1}{|c|}{ Factor } & \multicolumn{1}{|c|}{ Component } \\
\hline Insufficient amount & Scheme \\
ineffective scheme & Scheme \\
No proper communication from & \\
Agriculture/Horticulture office & Communication \\
No proper communication from & \\
AIC & Communication \\
No Proper information about & \\
CPIS & Communication \\
Difficult Claim Procedure & Claim \\
Franchise limit & Scheme \\
Delay in Settlement & Claim \\
Doesn't cover all palms & Scheme \\
limited time bound for claiming & Scheme \\
No follow-ups by authority & Communication \\
100\% compensation is not given & Scheme \\
\hline
\end{tabular}

Source: Worked out from survey data (2011-12)

Table 5. Kaiser-Meyer-Olkin (KMO) and Bartlett's Test - drawbacks

\begin{tabular}{|l|l|r|r|r|}
\hline \multicolumn{2}{|c|}{ Test } & Kerala & $\begin{array}{l}\text { Goa- } \\
\text { Maharashtra }\end{array}$ & $\begin{array}{l}\text { Karnataka- } \\
\text { Tamil Nadu }\end{array}$ \\
\hline $\begin{array}{l}\text { Kaiser-Meyer-Olkin } \\
\text { Measure of Sampling } \\
\text { Adequacy }\end{array}$ & & & \\
\hline Bartlett's & Approx. & & 0.589 & 0.521 \\
Test of & Chi- & & & \\
Sphericity & Square & 673.54 & 374.898 & 267.196 \\
& df & 66 & 66 & 66 \\
& Sig. & 0 & 0 & 0 \\
\hline
\end{tabular}

Source: Worked out from survey data (2011-12) 
Cord 2013, 29 (1)

Table 6. Component Matrix - drawbacks of CPIS

\begin{tabular}{|c|c|c|c|c|c|c|c|c|c|c|c|c|c|c|}
\hline & \multicolumn{4}{|c|}{ (a) Kerala (Component) } & \multicolumn{5}{|c|}{ (b) Goa-Mah (component) } & \multicolumn{5}{|c|}{ (c) Kar-TN (component) } \\
\hline & 1 & 2 & 3 & 4 & 1 & 2 & 3 & 4 & 5 & 1 & 2 & 3 & 4 & 5 \\
\hline Insufficient amount & 0.823 & 0.102 & -0.060 & -0.030 & 0.707 & 0.375 & -0.300 & 0.150 & -0.430 & 0.725 & 0.336 & -0.160 & -0.010 & 0.347 \\
\hline Ineffective scheme & 0.698 & 0.232 & -0.210 & 0.123 & 0.576 & -0.171 & 0.308 & 0.044 & 0.401 & 0.614 & -0.280 & 0.279 & -0.030 & -0.020 \\
\hline $\begin{array}{l}\text { No proper communication from } \\
\text { agriculture/Horticulture office }\end{array}$ & -0.040 & 0.121 & 0.663 & 0.223 & -0.510 & 0.067 & 0.624 & 0.391 & 0.091 & -0.310 & 0.579 & -0.370 & -0.150 & 0.233 \\
\hline $\begin{array}{l}\text { No proper communication from } \\
\text { AIC }\end{array}$ & -0.120 & -0.410 & 0.587 & 0.407 & 0.306 & -0.294 & 0.677 & 0.147 & -0.300 & -0.380 & 0.634 & 0.495 & 0.094 & -0.140 \\
\hline $\begin{array}{l}\text { No Proper information about } \\
\text { CPIS }\end{array}$ & 0.590 & 0.037 & 0.402 & -0.110 & -0.540 & 0.290 & 0.558 & 0.276 & -0.180 & -0.310 & 0.673 & -0.450 & 0.205 & 0.194 \\
\hline Difficult Claim Procedure & -0.290 & 0.596 & 0.302 & -0.090 & 0.048 & 0.548 & -0.460 & -0.460 & 0.061 & 0.322 & -0.440 & 0.506 & 0.362 & 0.312 \\
\hline Franchise limit & 0.634 & -0.470 & -0.280 & -0.030 & 0.574 & -0.490 & -0.250 & 0.289 & 0.353 & 0.681 & 0.001 & -0.190 & 0.016 & 0.312 \\
\hline Delay in Settlement & 0.670 & 0.351 & -0.120 & 0.100 & -0.200 & 0.660 & -0.070 & 0.443 & 0.208 & -0.110 & 0.182 & 0.712 & 0.116 & -0.450 \\
\hline Doesn't cover all palms & 0.557 & 0.216 & -0.260 & 0.272 & 0.592 & 0.104 & -0.570 & 0.059 & 0.047 & 0.635 & -0.190 & -0.220 & 0.136 & 0.485 \\
\hline limited time bound for claiming & -0.210 & 0.688 & -0.040 & 0.216 & 0.164 & 0.614 & 0.313 & 0.269 & 0.492 & -0.120 & 0.248 & 0.744 & 0.392 & 0.183 \\
\hline No follow-ups by authority & -0.320 & 0.195 & 0.407 & 0.299 & 0.147 & 0.360 & 0.743 & -0.280 & -0.050 & 0.010 & 0.729 & 0.229 & -0.200 & -0.400 \\
\hline $\begin{array}{l}100 \% \text { compensation is not } \\
\text { given }\end{array}$ & 0.356 & 0.211 & -0.140 & -0.270 & 0.806 & 0.247 & -0.270 & -0.180 & 0.310 & 0.634 & 0.522 & 0.056 & 0.388 & 0.001 \\
\hline
\end{tabular}

Source: Worked out from Survey data (2011-12) 
The component matrix of drawbacks identified in Kerala regions is given in Table 6 (a). The first component may be aptly termed as scheme particulars; the second as claiming particulars and the third factor as communication particulars. If the first component is analysed, it can be identified that inadequate compensation is the main drawback identified with the CPIS, followed by an ineffective scheme which is mainly due to the terms and conditions of the CPIS. Franchise limit and non-coverage of all palms are the third and fourth variables on which the first factor has higher loading. Claiming particulars such as limited time frame for claiming, and difficulty in procedures, constitute the second component. Lack of communication and follow-ups from the part of officials concerned and lack of information about the CPIS are major reasons which could be clubbed together to understand the third component. The main issue of CPIS in Kerala is with regard to the scheme particulars/conditions. The second major issue is with regard to the procedure of claiming and subsequent settlement process. The third issue is lack of communication between the farmer and the authorities concerned.

The first component in the case of Goa, scheme particulars, may also be listed as variables like non-payment of 100 percent compensation, insufficiency in amount, noncoverage of all palms, ineffectiveness of the scheme, and franchise limit, have the highest loading on this factor. The second factor is claiming particulars. Based on growers' opinion, delay in settlement and difficulty in claim procedure get the highest factor loading in the second component. Communication, the third component, is connected with such variables as lack of follow-ups by the authorities, lack of information about CPIS, and lack of communication from the official concerned, claim the highest loading on this factor. The detailed factor analysis of perception by growers of Goa-Maharashtra region regarding the drawbacks of CPIS is shown in Table 6 (b).

Issues with scheme particulars, followed by communication issues are identified as components 1 and 2, respectively, based on the perception of respondents of Karnataka-Tamil
Nadu region. The third component is comprised of the claiming particulars. The component matrix derived from the analysis is shown in Table 6 (c). Compared to the first two regions, there is difference in the perception of respondents in Karnataka-Tamil Nadu region as they have identified the communication issues as the second major drawback of the CPIS. Here, it is important to mention that as there is lack of communication between the growers in Karnataka-Tamil Nadu region and the authorities. Hence, there is further scope for improvement of communication network so as to ensure that the benefits of the CPIS reach the needy.

\section{Suggestions for improving CPIS}

Growers were asked to provide suggestions for the effectiveness and improvement of CPIS. 12 suggestions were reduced to three factors viz. suggestions with regard to scheme particulars, communication, and claiming procedures. Factor analysis was performed to identify the rank. Variables identified and their categorization is depicted in Table 7. Across regions, the KMO measure of sample adequacy shows a value of greater than 0.5 and hence recommends the analysis to proceed. Bartlett's Test is also significant and its associated probability is less than .05. Results of KMO and Bartlett's Test are portrayed in Table 8.

Table 7. Suggestions for the improvement of CPIS

\begin{tabular}{|l|l|}
\hline \multicolumn{1}{|c|}{ Suggestion } & \multicolumn{1}{|c|}{ Component } \\
\hline Cover all palms & Scheme \\
Increase compensation amount & Scheme \\
Early settlement & Claim \\
Increase claiming period & Claim \\
simplify claiming procedure & Claim \\
Provide proper information about & Communication \\
CPIS and its functioning & \\
$\begin{array}{l}\text { Frequent inspection/ follow-ups } \\
\text { from AIC }\end{array}$ & Communication \\
Remove franchise limit & \\
popularize the scheme & Scheme \\
Subsidy for baby palms until they & Communication \\
become matured & Scheme \\
lump sum premium for more tenure & Scheme \\
100\% compensation & Scheme \\
\hline
\end{tabular}

Source: Worked out from survey data (2011-12) 
Table 8. Kaiser-Meyer-Olkin (KMO) and Bartlett's Test suggestions

\begin{tabular}{|c|c|c|c|c|}
\hline \multicolumn{2}{|c|}{ Test } & Kerala & $\begin{array}{l}\text { Goa- } \\
\text { Maharashtra }\end{array}$ & $\begin{array}{l}\text { Karnataka- } \\
\text { Tamil Nadu }\end{array}$ \\
\hline \multicolumn{2}{|c|}{$\begin{array}{l}\text { Kaiser-Meyer-Olkin } \\
\text { Measure of Sampling } \\
\text { Adequacy }\end{array}$} & 0.590 & 0.544 & 0.501 \\
\hline $\begin{array}{l}\text { Bartlett's } \\
\text { Test of } \\
\text { Sphericity }\end{array}$ & $\begin{array}{l}\text { Approx. } \\
\text { Chi- } \\
\text { Square } \\
\text { df } \\
\text { Sig. }\end{array}$ & $\begin{array}{r}959.118 \\
66.000 \\
0.000 \\
\end{array}$ & $\begin{array}{r}259.367 \\
66 \\
.000 \\
\end{array}$ & $\begin{array}{r}251.889 \\
66 \\
.000 \\
\end{array}$ \\
\hline
\end{tabular}

Source: worked out from survey data (2011-12)

Suggestions by growers in Kerala region show that in the first component, the majority of loadings are covered by scheme particulars; followed by the claiming particulars in the second component and the third component is comprised of communication particulars. Major suggestions provided by growers in Kerala were to increase the compensation amount, subsidize new palms, payment of 100 percent compensation, lump sum premium for more tenure, removal of franchise limit and coverage of all palms. Suggestions in component 2 comprised of early settlement, simplification of claim procedures and increasing claiming period. Suggestions with regard to communication are shown as component 3 , which include providing information about CPIS and its functioning, follow-ups by the AIC and popularizing the scheme.

Major suggestions of the respondents in Goa-Maharashtra are with regard to scheme particulars followed by claiming procedures and lastly with regard to improvement of communication about CPIS. In the first component, majority of loadings are covered by scheme particulars such as coverage of palms, compensation, franchise limit, etc.; followed by the claiming particulars like early settlement, claiming period and simplification of procedures involved in claiming. In the second component and the third component are dealing with communication particulars.

In the first component, majority of loadings are covered by scheme particulars and hence the major suggestion is with regard to scheme particulars in Karnataka-Tamil Nadu region. The remaining communication particulars get in as the second and the third components which encompass the claiming particulars. The region-wise combined component matrix of suggestions is illustrated in Table 9.

\section{Conclusion and Policy Options}

Coconut palm insurance plan has emerged as an important agricultural policy measure in the Eleventh Five Year Plan with the objective of equipping and assisting coconut growers to minimize the loss in the event of natural calamities and diseases. Analyses and inferences point out that growers across the regions accept that the scheme is necessary for a crop like coconut. To a certain extent, the scheme seems to have achieved its goal. Premium subsidy or premium sharing is an important feature of the scheme. Agriculture/horticulture offices are the agencies which are directly dealing with the growers regarding CPIS and hence they play a pivotal role for the success of the scheme. Prompt and fast settlement of claims will help the scheme to continue. In Kerala, rate of settlement as well as period of settlement are very high, whereas in the other two regions in general and Goa-Maharashtra region in particular, cases of denial of compensation/nonsettlement are high. Both late settlement and non-settlement of claims by the authorities scuttle the success, of the scheme. Adequacy of compensation is very low in Goa-Maharashtra region mainly due to higher yield per palm. Income loss incurred to the farmer as a result of the loss of palm is not considered while calculating compensation amount. This needs to be redressed by incorporating average returns of the grower from the lost palms for calculating claim amount, so as to provide subsidy to the new palm, which will in turn ensure a better replanting rate.

The CPIS was implemented as a pilot scheme and hence a few policy options are of paramount importance when the scheme is to be implemented on a long term basis. The estimation of the compensation should be suitably revised to a reasonable level on the basis of age of the palm and its average annual 
Cord 2013, 29 (1)

Table 9. Component Matrix - suggestions for improvement of CPIS

\begin{tabular}{|c|c|c|c|c|c|c|c|c|c|c|c|c|c|c|}
\hline & \multicolumn{4}{|c|}{ (a) Kerala Component } & \multicolumn{5}{|c|}{ (b) Goa-Mah Component } & \multicolumn{5}{|c|}{ (c) Kar-TN Component } \\
\hline & 1 & 2 & 3 & 4 & 1 & 2 & 3 & 4 & 5 & 1 & 2 & 3 & 4 & 5 \\
\hline Cover all palms & 0.515 & -0.45 & -0.49 & -0.112 & 0.647 & 0.287 & -0.565 & 0.01 & 0.165 & 0.649 & -0.258 & -0.327 & 0.329 & 0.211 \\
\hline Increase compensation amount & 0.705 & -0.5 & 0.193 & 0.109 & 0.665 & 0.227 & 0.027 & 0.134 & 0.483 & 0.465 & -0.114 & -0.455 & 0.464 & 0.422 \\
\hline Early settlement & -0.06 & 0.797 & 0.292 & -0.042 & 0.368 & 0.62 & -0.13 & 0.402 & 0.185 & 0.585 & -0.227 & 0.318 & -0.49 & 0.194 \\
\hline Increase claiming period & -0.38 & 0.636 & 0.037 & -0.123 & 0.025 & 0.641 & -0.529 & 0.229 & -0.06 & 0.064 & -0.064 & 0.773 & 0.387 & -0.09 \\
\hline simplify claiming procedure & -0.05 & 0.721 & 0.269 & -0.029 & -0.48 & 0.609 & 0.251 & 0.01 & 0.252 & 0.473 & -0.011 & 0.679 & -0.26 & 0.191 \\
\hline $\begin{array}{l}\text { Provide proper information about } \\
\text { CPIS and its functioning }\end{array}$ & 0.248 & -0.03 & 0.768 & 0.131 & 0.036 & -0.01 & 0.728 & 0.037 & 0.524 & -0.53 & 0.56 & 0.199 & 0.274 & 0.384 \\
\hline $\begin{array}{l}\text { Frequent inspection/ follow-ups } \\
\text { from AIC }\end{array}$ & 0.077 & -0.05 & 0.723 & 0.135 & -0.27 & -0.52 & 0.591 & -0.03 & 0.278 & 0.392 & 0.457 & -0.446 & 0.187 & 0.388 \\
\hline Remove franchise limit & 0.528 & 0.346 & -0.47 & 0.254 & 0.547 & -0.54 & 0.452 & -0.02 & -0.06 & 0.507 & -0.09 & 0.328 & -0.49 & -0.15 \\
\hline popularize the scheme & -0.26 & 0.243 & 0.574 & 0.039 & 0.025 & 0.024 & 0.73 & 0.006 & 0.182 & -0.38 & 0.566 & 0.138 & 0.165 & -0.09 \\
\hline $\begin{array}{l}\text { Subsidy for baby palms until they } \\
\text { become matured }\end{array}$ & 0.634 & -0.11 & -0.22 & 0.081 & 0.684 & 0.428 & 0.256 & 0.169 & -0.29 & 0.518 & 0.234 & 0.434 & 0.144 & 0.386 \\
\hline $\begin{array}{l}\text { lump sum premium for more } \\
\text { tenure }\end{array}$ & 0.537 & 0.109 & -0.27 & 0.27 & 0.423 & 0.307 & -0.449 & -0.29 & -0.23 & 0.472 & 0.224 & -0.463 & 0.357 & -0.34 \\
\hline $100 \%$ compensation & 0.592 & -0.09 & 0.031 & 0.409 & 0.521 & 0.362 & 0.171 & 0.571 & -0.23 & 0.721 & 0.235 & 0.191 & 0.035 & -0.47 \\
\hline
\end{tabular}

Source: Worked out from survey data (2011-12) 
potential yield during the lifespan. Lack of information and communication has been identified as one of the major issues with CPIS. Effective use of ICT can ameliorate the situation. This is all the more important in States like Maharashtra, Karnataka and Tamil Nadu where the growers have to traverse long distance to reach the respective offices to report their claims or to clarify their doubts. One possible way out is to popularize the scheme through advertisements preferably in Radio and through visual media as well as by mobile phone SMS (in local language). Provision for loss reporting through phone whereby the growers can inform the authorities about the loss incurred by making a call to the customer care number for which they may be provided with an acknowledgement, which they can use for future queries. As per the present clause, loss reporting time is 7 days failing which claims will not be entertained. This is an unnecessary clause which should be changed to 30 days as the minimum period for reporting compensation. Growers having less than 10 palms are ineligible to join the scheme. This clause may suitably be removed so as to ensure involvement of small/marginal growers. Small growers should be given 100 percent premium subsidies by the CDB. The franchise clause should also be removed. The very purpose of CPIS is to provide compensation to the coconut palm growers in the unfortunate event of loss of palm. However, certain terms and conditions result in denial of compensation to the needy and deserving growers. Only if these clauses are suitably amended, it can be ensured that the objectives of the scheme are achieved to its fullest.

The results of factor analysis on the grower's perception regarding the drawbacks and suggestions about the CPIS show considerable uniformity across regions. Issues relating to scheme particulars, communication and claim related factors, are also listed as drawbacks. Grievances of the growers seem to be genuine and based on this they have made some suggestions. This would help to contemplate for reframing the scheme in such a way so as to ensure optimum level of benefit to the growers.

\section{Acknowledgement}

The authors would like to acknowledge the financial support from the Coconut Development Board, Cochin for entrusting a study concerning the central theme of the article.

\section{References}

Pandey, V.K., K.S. Suhag, and R.C. Hasija, 1981. An economic study on feasibility of crop insurance in Haryana State. Agricultural Situation in India, 35 (10): 757-767.

Raju, S.S. and R. Chand. 2008. Agricultural Insurance in India Problems and Prospects. National Centre for Agricultural Economics and Policy Research, NCAP Working Paper No. 8.

Ramaswami, B. 1993. Supply response to agricultural insurance - Risk reduction and moral Hazard effects. American Journal of Agricultural Economics, pp. 914-923.

Singh, I.J. 1972. A feasibility study of crop insurance in Uttar Pradesh. Indian Journal of Agricultural Economics, 38 (2). 